Canadian University Music Review

Canadian University Music Review

Revue de musique des universités canadiennes

\title{
Charles M. Keil. Tiv Song. Chicago: University of Chicago Press, 1979, xiii, 301 pp.
}

\section{John Shepherd}

Numéro 3, 1982

URI : https://id.erudit.org/iderudit/1013836ar

DOI : https://doi.org/10.7202/1013836ar

Aller au sommaire du numéro

Éditeur(s)

Canadian University Music Society / Société de musique des universités

canadiennes

ISSN

0710-0353 (imprimé)

2291-2436 (numérique)

Découvrir la revue

Citer ce compte rendu

Shepherd, J. (1982). Compte rendu de [Charles M. Keil. Tiv Song. Chicago: University of Chicago Press, 1979, xiii, 301 pp.] Canadian University Music Review / Revue de musique des universités canadiennes, (3), 216-221.

https://doi.org/10.7202/1013836ar

All Rights Reserved (C Canadian University Music Society / Société de musique des universités canadiennes, 1982
Ce document est protégé par la loi sur le droit d'auteur. L'utilisation des services d'Érudit (y compris la reproduction) est assujettie à sa politique d'utilisation que vous pouvez consulter en ligne.

https://apropos.erudit.org/fr/usagers/politique-dutilisation/ 
Inevitably there are a number of annoying misprints which should be corrected in a later edition: for example, the date of Coulthard's String Quartet No. 2 should be 1954, revised 1969 (p. 22); Saarinen, not Saainen (p. 70); Tafelmusik, not Tafel Musik (p. 118); Enkidu, not Enkido (p. 144); C.F. Peters, not C.P. Peters (p. 152); commissioned, not comissioned (p. 180); Symphonic Ode, not Symphonique Ode (p. 246); Bläsermusik, not Blässermusik (pp. 274 \& 281). Finally, many of the references to recordings are out-of-date and need to be amplified and/or corrected.

The Ford and Bradley books are welcome additions to the material on Canadian music. They can be highly recommended, and both authors and publishers have earned our gratitude for providing two badly needed reference works.

Elaine Keillor

Charles M. KeIl. Tiv Song. Chicago: University of Chicago Press, 1979, xiii, $301 \mathrm{pp}$.

Tiv Song, it would be safe to say, is not a standard ethnomusicological work. There are two reasons for this. Firstly, the book is only an "introduction to future research on Tiv song and dance. It cannot be otherwise, for I have not done the fieldwork that an ethnographic treatment requires" (p. 1). Secondly, Keil is singularly unimpressed with extant musicological and cultural anthropological theory. The former he finds largely ethnocentric, unable to deal with the fact that many African societies do not possess a semantic category, "music," let alone our concern for frozen, abstract notions such as "rhythm" and "harmony." The latter is criticized as "idealist" in assuming that "'styles' of expression have a life and logic of their own" (p. 7), "floating symbolically above the events of everyday life" (p. 6). The lack of full social contextualization in attempts to understand "cultural systems" allows much cultural anthropology, in Keil's view, to become a servant of imperialism. "Traditional" societies are reified and packaged to make them amenable to the imposing weight of Western intellectual tradition, a process furthered ethnomusicologically through the application to "pre-literate" musics of categories of analysis having little in common with the categories of musical understanding developed by the "pre-literate" societies themselves. Keil senses, therefore, that "Western thought has been, is, will always be, the primary obstacle between me and Tiv imo [song]" (p. 182).

The lack of systematic fieldwork (attributable to some shortcomings on the author's part as well as to the Nigerian civil strife of 1966) and of a firm theoretical approach clearly lays the book open to criti- 
cism on the part of professional anthropologists and ethnomusicologists. But, as Keil observes, a certain "inadequacy" of approach may be beneficial:

Put in negative and defensive terms, if imperialism is evil and anthropology serves it, then doing anthropology badly (thin data, weak scholarship) and boldly (following hunches, admitting errors) may be the best we can do. But this is to look at this book as though we are trapped within the anthropological profession. We are not trapped, unless we choose to be (p. 5).

What Tiv Song indisputably achieves, then, is the formulation of questions, both substantive and theoretical, as a result of contact with Tiv society and song, rather than a systematic and "finished" ethnography shaped by questions and pre-suppositions important to cultural anthropology and ethnomusicology as Western academic disciplines.

Two messages emerge clearly from Tiv Song. The first is that one can only begin to make adequate sense of the way in which the Tiv create, use, and understand their music, as well as of the internal structure of the music itself, if one approaches all these aspects of Tiv musical activity as full and organically integrated expressions of all other aspects of Tiv life. Music cannot be understood as having significance just in relation to other "cultural forms," to some kind of ethereal cultural superstructre or cultural "ethos" which then determines "less artistic" levels of action and behavior. What snapped into place for Keil in writing the book, and what pushed him increasingly closer to a "materialist" or Marxist stance, was the realization that

in trying to describe how songs fit in with "everthing else" in a cultural pattern, I was also discovering that "everything else"was as simple as roof structure and compound layout, as basic as everyday conversations and social interactions, as direct and urgent as the struggle for classless society (p. 7).

Tiv society is characterized, as are many, by tensions centering on power, sex, and the necessity of food. The more influential an elder becomes, the more circumspect he must become in his use of that influence, since the Tiv view is that power and influence can only be gained at the expense of others. The idea that political strength goes hand in hand with evil is expressed through a belief in evil beings (mbatsav) who thrive cannibalistically on the flesh of the virtuous:

The people of tsav, the mbatsav, are alleged to leave their sleeping bodies for nightime cabals, during which they exhume corpses, revive them, and then slaughter, divide, and consume them, in a never-ending round of acquiring and paying flesh debts to each other. Some deaths are necessary: a parent expects to lose a child sooner or later, for the mbatsav in their benign aspect must sacrifice to repair the land and increase general fertility. Some deaths are expected: an elder cannot last forever. But the mbatsav are known to be prone to greed; they are all too likely to desire 
an increase in their powers at the expense of others. Tsav grows with age, and all elders, all survivors, possess it (p. 18).

If misfortune befalls someone in a compound, it becomes necessary to extract a confession from the person harboring the evil tsav. Since elders possess more tsav than others, they are more suspect, and if a confession is forthcoming, the power and influence of the confessing elder will diminish accordingly. Many Tiv songs are composed to praise great men. But many are also composed for the express purpose of drawing attention to the wrongdoings of prominent people, as well as for underlining the stupidity and vulnerability of those in authority.

Women in Tiv society are a constant source of tribulation to men. Women not only control reproduction (quite obviously), but can leave a marriage they find unsatisfactory with relative ease. They also have a greater control over the tools of production than men would like. Although not possessing much power in a political sense, women are nonetheless more than capable of putting men "in their place" in other ways, thus emphasizing the forces of social solidarity. It is interesting, then, that the most reliable haven in the face of the forces of evil and usurpation in Tiv society is to be found in an individual's matriline. It is equally interesting that many Tiv songs are laments on the part of men as to the way they have been treated by women, and serve to re-institute, if only in fantasy, the rightful status of men. Men vie for the center of power in a continuous dynamic which makes that power difficult to retain as a seeming compensation for their insecurity vis-à$v$ is the relative social, biological, and agricutural potency of women. Perhaps, as Keil says, "men do most of the singing in Tivland, and storytelling as well, because of their 'empty stomachs'" (p. 85). The sexual symbolism of such a dialectic would not be lost on the Tiv. Men make a straight-line, individualistic thrust for the center of power whose potential for evil is absorbed concentrically through the organic fertility of women.

Tiv life, concludes Keil, is thus about circles and angles, about the (female) collective and beneficial social containment of (male) potential individual supremacy and evil. Men feed their tsav, their life force, on elements of Tiv life in order to keep in motion the fundamental dynamics of Tiv society. They can only contribute by taking, and only by absorbing what is given can the "female" elements of Tiv society be potentiated and gain strength. The biological becomes a code for the social.

The theme of circles and angles finds not only visual expression through the manner in which roof huts are constructed, the decoration of calabashes, pots, and walking sticks, and the patterns used in body scarification, but also aural expression through the composition, performance, and internal structure of music. Composers "receive" songs while lying quietly on their backs, away from women, staring up at the roof of a hut (which carries a logogram of the dynamic patterning of 
Tiv life). To compose a song is a dugh imo, the verb dugh literally translating as "to effect the quick emergence of something after a steady preparation" (p. 31), and having application in many other situations such as harvesting yams, giving birth, and so on. Composing is an essentially "female" process, an organic process, achieved in isolation from women while contemplating the fundamental dynamics of Tiv life. To perform a song, however, (gber) is to cut it or incise it into public consciousness. It is an essentially "male" ejaculatory process. Songs open in a loud, declamatory way, slowly diminishing as the singer nears the end. If a singer fails to hold the attention of the audience, another singer might start a different song before the first singer has finished. Two songs will thus be sung at once until the audience reaction determines who will cease. The center of power is difficult to maintain.

These sexual and political tensions find expression in the structure of songs themselves, and it is through making such structural homologies that Tiv Song attests most successfully to the affective immediacy of song in Tiv life:

Songs move downward in overall melodic shape, and usually in internal phrases as well. The striking use of wide descending intervals, for example, "interlocked fifths," presents a drive toward base or ground, from high to low, from beginning to end, or from circumference to center along radii in the spatial model, from male to female in the sexual metaphor. Song intervals in general and the high proportion of wide intervals in particular assert angularity, discontinuity, a mode of becoming. The repetitive monotones, tonics, and sense of "double duration tones" provide the ground of being, the concentric circles, a sense of intension against which the intervals work in a friction of essential parts (pp. 255-56).

Tiv song is thus, in all its aspects, about the fundamental social structuring of Tiv life, whether "material" or "symbolic." It summarizes, suffuses, and transcends the notion of life as energy exchange which is at "the core of the Tiv belief system" (p. 89). Song resolves tension, prevents things getting out of hand:

These energetic struggles with the problems of power and sex are often suffused with a concern for that ultimate energy source, food: the problem of survival and its corollary question of death or sacrifice - that is, whose energies are to be exchanged for whose? Song energy, in collective fantasy at least, seems capable of "solving" all these problems, singly or in combination; power, sexual satisfaction and food come to the singer in tales (pp. 94-95).

Song is energy. Song is a basic life force for the Tiv.

The second major message to emerge from Tiv Song is that ethnomusicology is not simply about understanding the musical systems 
of other cultures (whether with phenomenological adequacy or not), but also and at the same time about understanding our own music and ourselves. We must be prepared to learn about our music and our society from other cultures. Idealism dictates that ethnomusicology should result in "'ethnographic presents' given from one anthropologist to others in the endless kula ring of professional reciprocity" (p.5). However, a more materialist approach recognizes: (a) that the music of other cultures is suffused with social structuring; (b) that our idealist attitudes toward our own music form but one aspect of the social construction of our own reality; (c) that the music of our own culture might, like that of many "traditional" societies, be likewise infused with social structuring; (d) that we fail to hear this and thus miss what our music has to tell us about ourselves; and (e) that we consequently fail to open our ears to what the music of other cultures might tell us about ourselves.

For example, Tiv society quite clearly possesses institutionalized forms of de-alienation from which we could learn:

On a small scale, with greater clarity, grounded Tiv being is quite similar, though not nearly so deadly, as the ungrounded American "higher standard of living." We both play the competitive zero-sum game - my success is your failure; A's loss is B's gain; our pleasure is the world's pain. Broadly speaking, Tiv are subject to the same explosions and implosions, aggressions and suicides, as their American counterparts, with the basic difference that in Tivland these processes are acknowledged, expressed in the idiom of tsav and known to be evil, while in America the language is one of "free enterprise," "positive thinking," "success," and climbing to the top over a pile of corpses is thought to be good and natural. Tiv play the zero-sum game to keep classes from forming and are relatively successful, while we play it more or less unwittingly to help the ruling class become richer and more secure. Finally, of course, the respected survivors of the American way have immense financial and technological power in their hands, the distrusted survivors of Tivland do not (pp. 21-22).

Song is but one way in which the Tiv prevent the kind of gross alienation that characterizes our own society. As Keil observes, "no Tiv is too big a man to be bothered by something; everyone has troubles to be soothed by songs" (p. 153). It therefore became a problem for one Tiv composer, Kuji Iyum, to understand why white men, who are so confident about themselves and their world, should sing:

... even the white man who has more money and is above all of us in the world, he does sing just like other people. When you tune the radio, one of the first things you hear will be his songs. He has everything, all the knowledge, but still he sings songs. So we should ask what has befallen him (quoted, p. 154).

What has befallen him, perhaps, is a curious deafness, an inability to sing his way out of trouble. 
It is not difficult to criticize some aspects of Tiv Song. At the outset, Keil admits that "asked to choose between superstructuralists and bassists, I am a bassist" (p. 7). Although traditional Marxism represents an advance over idealism in stressing the social construction of all aspects of life, its desire to assign a higher status to action rather than thought is evidence of an inverse adherence to the fundamental epistemological categories of Western thought which made idealism possible in the first place. Tiv Song breathes a humanism which is openly acknowledged by the author, and which has its roots as a sociological approach in American Pragmatism, a philosophy whose very aim was to collapse categories of thought and action in an attempt to locate motivation for all human activity in the inescapably organic wholeness of people's existential and phenomenological being. The belief that society creates people must also allow, in other words, that people create society. The choice of materialism is thus not the only one open to those who wish to acknowledge the pervasiveness of the social.

However, to harp on a lack of theoretical focus, or on possible superficialities in anthropological or musicological analysis, is to miss the significance of Tiv Song. The book represents a challenge which must be taken up if ethnomusicology and musicology are to make a substantial contribution to our understanding of ourselves (and what other, ultimate aim can there be for any of the humanities or social sciences?). As Keil notes:

Compared to Tiv activity in the song and dance spheres ... our passivity is very impressive. Over the past few generations we have been increasingly willing to let others make music for us. If we continue to tune into radio and television, if we keep consuming things called "singles" and "albums" and "tapes" by the billion rather than make songs for ourselves, we should not be surprised to find that these songs, and the tales and dances that are sold to us too, are designed to help us escape our reality. Certainly they don't help us to confront it. Fieldwork in Nigeria taught me that reality moves right along, with or without you; that trying to ignore or escape it is of ten fatal and that - to answer Kuji Iyum's basic question - only madmen and specialists can face reality "in a completely confident state." In these times, even they have their troubles and worries (p. 258).

If the notion that we need to sing our way out of trouble seems fanciful, then that is only because we have neither adequately stressed the intimate relationships that exist between music and all aspects of society, nor sufficiently explored their nature. 